\title{
Application of Matlab in Control Theory Teaching
}

\author{
ZHOU $\operatorname{Jin}^{1, a, ~ * ~}$ \\ ${ }^{1}$ College of Engineering, Shanghai Second Polytechnic University, Shanghai, 201209, China \\ azhoujin@sspu.edu.cn, ${ }^{*}$ corresponding author
}

Keywords: Matlab; Control Theory; Computer Aided Instruction.

\begin{abstract}
In order to further improve teaching quality, software Matlab is applied in control theory series courses teaching. The details of the measures are discussed in this paper, which involves computer aided instruction, course content enrichment, and experiment design. These measures have obtained good effect and feedback in practice. Using courseware during lectures and individual studies enriches instruction content and improves comprehension of abstract concepts. Hand-on experiments deepen students' understanding of automatic control principles and allow them to practice computer skills for analysis and design of control systems.
\end{abstract}

\section{Introduction}

Control theory series courses are important specialized courses in automation major. Many bachelor degree programs, such as applied mathematics, electrical engineering, mechatronics, have include relevant courses in curriculum. As these courses themselves involve abundant abstract concepts and theoretical reasoning, students often find it difficult to understand, for example, transient response analysis, root locus, bode diagram, Lyapunov stability. Also, this course covers the modeling, analysis and design of control systems by means of mathematics and diagrams. The students with relatively weak mathematic foundation would have great difficulty in applying the concepts to practical control systems.

On the other hand, with rapid development of computer aided technology today, traditional course content should be updated to adapt to requirements of times. Software MATLAB is known as a powerful scientific and engineering tool for fast and reliable numerical computation and graphical functions [1]. It is a useful means to analyze and design complex control systems using computer. Usage of Matlab helps students' understanding of control theory content, improve their computer skills, and foster students' independent thinking ability. From our former teaching experience, some problems in teaching and organization were identified. Therefore some teaching reform measures have been taken and the details were given in this paper.

\section{Problems Identified during Teaching Practice}

Teaching is a continuously improving process [2][3]. From lessons in recent years we summarized 3 problems. Firstly, though the technique of automatic control has been applied in all walks of life, the textbook materials are more focused on theoretical reasoning and mathematical calculation. In some sense, these theoretical contents thwart students' interest of the relevant courses. For example, the linkage between pole placement and performance measure of control system seems intangible to some students. They only memorized the calculation procedure to pass the examination. Secondly, computer aided analysis and design in control field has been popular for engineers and researchers at present. Certain class hours should be given on this regard. The combination of computer skills and specialized knowledge is helpful for students in future career. The third problem is with teaching method. The traditional blackboard teaching method can not show the convenience of control theory analysis in high-order systems. Usage of powerpoint files speeds up the teaching progress, but students may not have enough time to comprehend the terms or take notes, and get absent-minded easily. Therefore, hand-on experimental experience is important for students.

With the help of Matlab, we try to address these problems with the following procedures: 
1. Some interactive courseware programs are implemented with Matlab. They can be demonstrated in class and employed on web. The immediate hand-on experience can help students to keep focused, strengthen the understanding of related concepts and activate memory.

2. Experiments using Matlab are carefully designed, covering main contents of classical automatic control theory and modern control theory. The instant visual effect of Matlab initiates students' interest and nurtures their problem-solving ability.

\section{Courseware Programs}

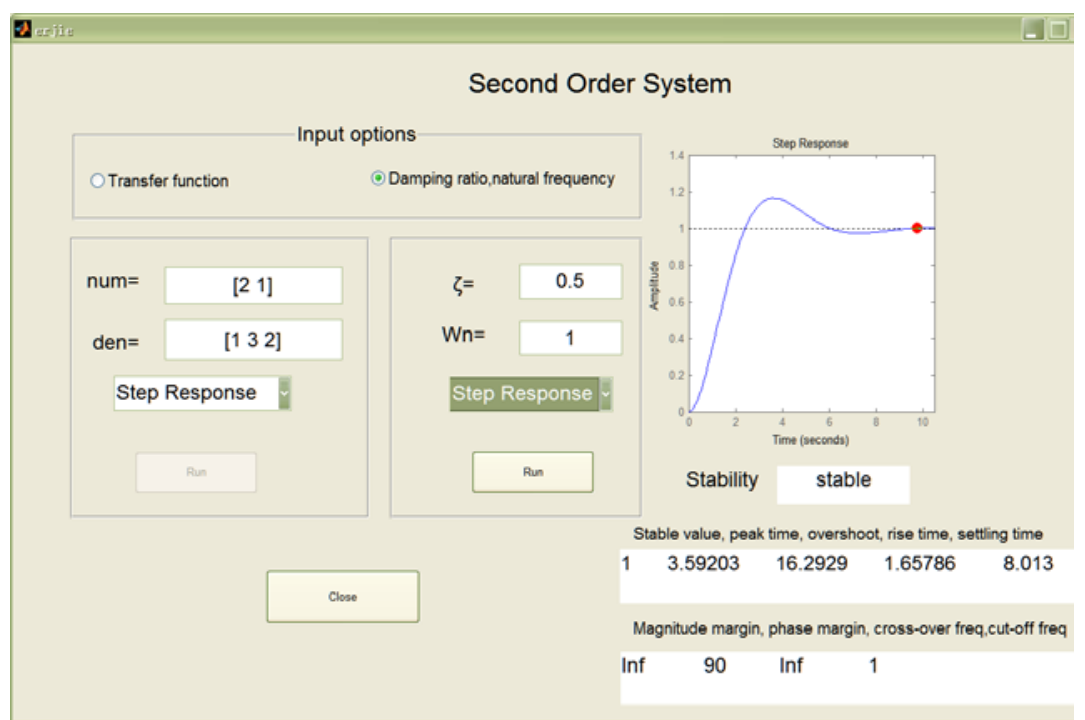

Fig. 1. Second order system analysis tool

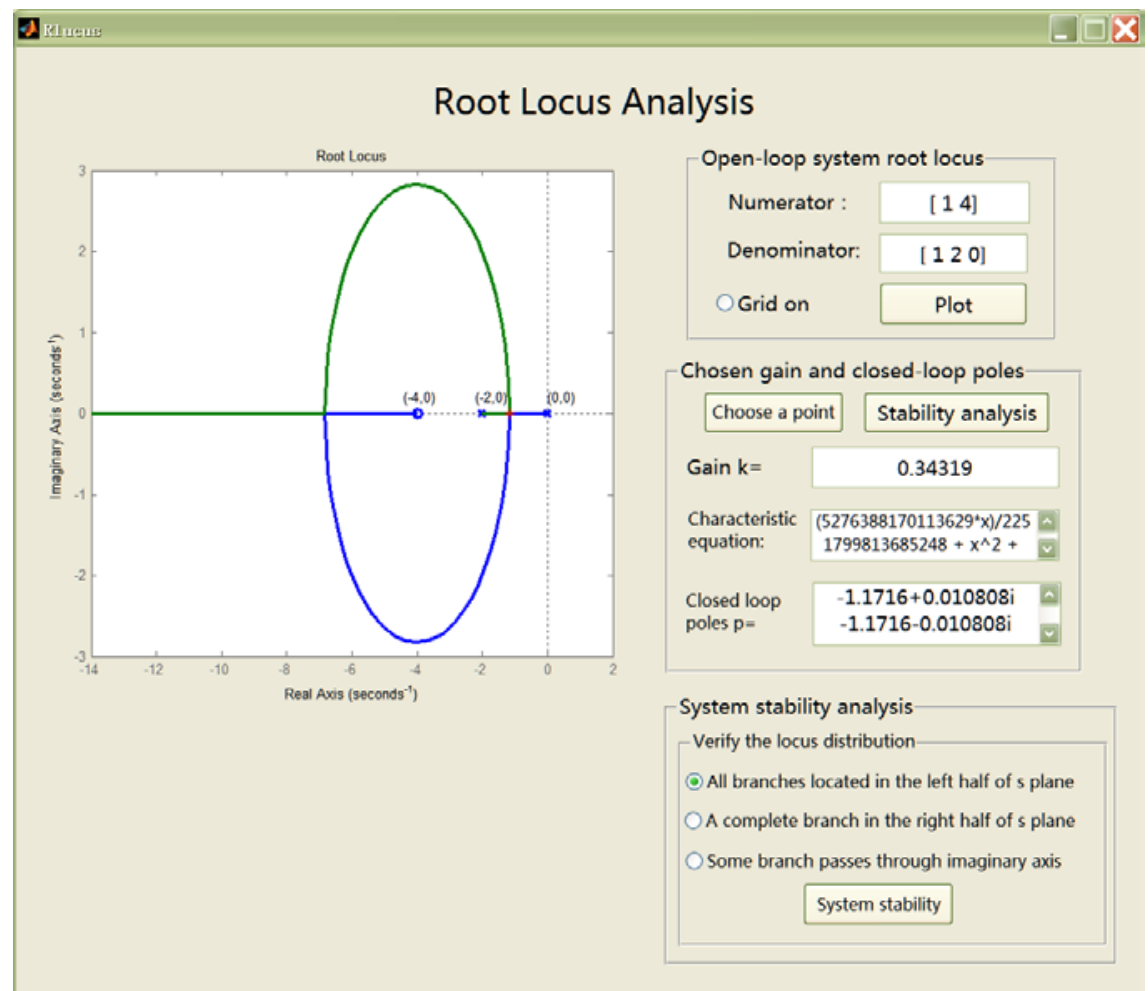

Fig. 2. Root locus analysis tool

Based on the past teaching experience, we developed several interactive courseware programs. Figs. 1 and 2 show the interfaces of second order systems analysis and root locus analysis. They are self-explained. Each can accept parameters which specify the system, and show its analysis in time 
domain or frequency domain. They save the time of drawing on blackboard and lets teachers thinking coherently of the content. The visualization of course content and instant figure demonstration arouses the students' learning interest both in automatic control theory and control system simulation. The result of using courseware for lectures in control theory is promising. [4]

With computer aided course instruction, students can concentrate on studying abstract concepts and arousing their motivation. The instant response given by courseware can help students try different combinations of parameters and improve understanding of basic principles.

\section{Experiment Design}

During lab hours, students should learn to develop analytic skills and solve elementary-level problems independently, as well as acquiring necessary specialized knowledge. A suitable textbook meeting all the course requirements is difficult to find. Some textbooks discuss programming with Matlab specifically and only cover little on its application in control systems. Some textbooks incorporated abundant abstruse control theory which is not suited for undergraduate students. Also, most of the examples and the assignments are universal mathematical models without clear engineering background. Therefore, the purpose to foster ability of solving practical engineering problem can be hardly accomplished.

Table 1 Experiments using Matlab

\begin{tabular}{|c|c|c|c|}
\hline Module & Content & $\begin{array}{l}\text { Class } \\
\text { Hours } \\
\end{array}$ & Type \\
\hline $\begin{array}{l}\text { Simulation of 2-Order } \\
\text { Systems }\end{array}$ & $\begin{array}{ll}\text { - } & \text { Modeling a RLC circuit } \\
\text { - } & \text { Modeling a pendulum } \\
\text { - } & \text { Solving differential equations } \\
\end{array}$ & 2 & Basic \\
\hline PID Control Systems & $\begin{array}{ll}\text { - } & \text { Usage of SIMULINK } \\
\text { - } & \text { Liquid level control for a water tank } \\
\text { - } & \text { Speed control for a DC motor } \\
\text { - } & \text { Tuning PID parameters }\end{array}$ & 2 & Comprehensive \\
\hline Time Domain Analysis & $\begin{array}{ll}\text { - } & \text { Overshoot calculation } \\
\text { - } & \text { Settling time estimation } \\
\text { - } & \text { Transient response plotting }\end{array}$ & 2 & Basic \\
\hline $\begin{array}{l}\text { Frequency Domain } \\
\text { Analysis }\end{array}$ & $\begin{array}{ll}\text { - } & \text { Transfer function calculation } \\
\text { - } & \text { Root locus plotting } \\
\text { - } & \text { Stability assessment }\end{array}$ & 2 & Basic \\
\hline $\begin{array}{l}\text { Compensation System } \\
\text { Design }\end{array}$ & $\begin{array}{ll}\text { - } & \text { Bode plotting } \\
\text { - } & \text { Series compensation design } \\
& \text { comparison of different } \\
& \text { compensation techniques } \\
\end{array}$ & 3 & Comprehensive \\
\hline State Space Modeling & $\begin{array}{l}\text { - Conversion between transfer function } \\
\text { and state space equations } \\
\text { - Zero-pole-gain model } \\
\end{array}$ & 2 & Basic \\
\hline Solving State Space Model & $\begin{array}{ll}\text { - } & \text { Transient response } \\
\text { - } & \text { Continuous and discrete models } \\
\end{array}$ & 2 & Basic \\
\hline $\begin{array}{c}\text { Controllability, } \\
\text { Observability and } \\
\text { Stability } \\
\end{array}$ & $\begin{array}{ll}\text { - } & \text { Controllability, observability criteria } \\
\text { - Lyapunov stability }\end{array}$ & 2 & Basic \\
\hline $\begin{array}{l}\text { State Feedback and } \\
\text { Observer Design }\end{array}$ & $\begin{array}{ll} & \text { State feedback } \\
\text { - } & \text { Observer design }\end{array}$ & 2 & Comprehensive \\
\hline
\end{tabular}

For these reasons, we designed experiments with emphasis on practical training. The details are shown in Table 1. New experiment guide books are written to serve the purpose. All the examples are 
meticulously chosen and the lab assignments are especially designed to train the students' comprehensive ability to use knowledge [5-7].

The application of Matlab increases the interaction between the teacher and students. In addition, the hand-on tasks challenge students to recall what they learned in control theory and practice computer programming knowledge immediately. In this way, teacher could deepen students' understanding of theoretical knowledge, encourage the independent thinking and enhance their problem-solving ability.

\section{Summary}

Based on the problems we identified during teaching control theory courses, some measures with the help of Matlab are taken to enrich course content and improve teaching quality. The attendance rate increases apparently, reaching almost $100 \%$. And the feedback from students is also positive. Improvement can be perceived from every aspect, ranging from students' attitude towards study, the lab reports submitted, student's consciousness of studying, to students' ability to discover problems, analyze problems, and solve problems independently. And they are prepared to engage in the graduation project and step into their work positions with necessary computer simulation skills.

Throughout the new course plan, the engineering students are encouraged to think, program, and debug independently. More specifically, they learn to apply the automatic control principles and computer technology flexibly to practical systems. As a result, it is observed that the enthusiasm of student's learning initiative is aroused and students' control system analysis skills are enhanced.

\section{Acknowledgments:}

This work was supported by the Key Course Construction Project of Shanghai Second Polytechnic University and the Shanghai Second Polytechnic University Key Discipline Construction-Automatic Measurement \& Control (No. XXKYS1402).

\section{References}

[1] http://www.mathworks.com

[2] J. Zhou, Z. Hu, H. Song, and G. Chen, Teaching Reform in the Course "Control Systems CAD" [C]. 2012 International Conference on Education Reform and Management Innovation (ERMI 2012), China: Shenzhen, December 4-5, 2012, 145-148.

[3] K. Ogata, Modern Control Engineering [M], Publishing House of Electronics Industry, Beijing, China, 2011.

[4] V. Kroumov, H. Inoue. Enhancing Education in Automatic Control via Interactive Learning Tools [C], Proceedings of the 40th SICE Annual Conference, Japan: Nagoya. July 25-27, 2001, 220-225.

[5] Y. Hou, Q. Ji, J. Zhang, J. Du, Basics of Modern Control Theory [M]. Peking University Press, 2006.1.

[6] http://www.engin.umich.edu/group/ctm/basic/basic.html

[7] H. Mao, X. Feng, W. Li, Research and Practice on the Teaching of Computer Simulation of Control Systems [J], Journal of Electrical \& Electronic Engineering Education, 2009, 31(z2),157-159. 